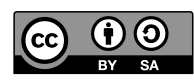

DOI: $10.4312 / \mathrm{mz} .56 .2 .73-84$

UDK 781.972:091(497.4Celje)"17/18"

\title{
RISM and Inventorying Early Music Manuscripts in Slovenia
}

\author{
Jana Erjavec \\ Research Centre of the Slovenian Academy of Sciences and Arts
}

\begin{abstract}
Since its inception, the project Répertoire International des Sources Musicales (RISM) has played a major role in the creation of an inventory of preserved early music heritage in Slovenia. This article presents the background and the current state of cooperation between Slovenian musicology and the RISM project, focusing on the latest additions to the online catalogue from the music collection of the Church of St Daniel in Celje.
\end{abstract}

Keywords: music manuscripts, music catalogues, RISM, Slovenian musicology, Church of St Daniel in Celje

\section{IZVLEČEK}

Vse od ustanovitve igra RISM pomembno vlogo pri popisovanju starejših glasbenih virov ohranjenih v Sloveniji. V prispevku je predstavljen razvoj ter trenutno stanje sodelovanja slovenske muzikološke stroke s projektom RISM s posebnim ozirom na glasbeno zbirko cerkve sv. Danijela v Celju, ki predstavlja najnovejši doprinos slovenske skupine za RISM k spletnemu katalogu.

Ključne besede: glasbeni rokopisi, glasbeni katalogi, RISM, slovenska muzikologija, cerkev sv. Danijela v Celju

This paper was written within the framework of junior researchers training (code 53501, 2019-2023), the research programme Researches in the History of Music in Slovenia (code P6-0004 (A), 2015-2021) and the research project Old Traditions in New Vestments: Musical and Textual Reworkings in the Performing Practices of Liturgical Music (code J6-1809, 2019-2022), financed by the Slovenian Research Agency (ARRS). 
The preservation and interpretation of (national) musical heritage is one of the main tasks of musicology. The possibility of a successful study of primary sources is based on thorough and extensive archive research and organisation.

More extensive archival research on the heritage preserved on the territory of the present-day Republic of Slovenia and on the relevant sources outside its present borders began in the 1950s, when Slovenian musicology began to cooperate with the newly founded Répertoire International des Sources Musicales (RISM). Since then, cooperation between Slovenia and RISM has gradually increased, culminating in the establishment of a national group for RISM at the Institute of Musicology of the Research Centre of the Slovenian Academy of Sciences and Arts (ZRC SAZU) in 1993. The members of the Slovenian RISM group at the institute have continued the cataloguing of the preserved heritage using the most modern computer systems provided by RISM and have supplemented the traditionally compiled data with additional content.

Despite the many advantages that cooperation has brought, there are still specific problems that the Slovenian musicologists involved in the creation of the national register are facing. The aim of this article is to present the role that RISM has played in the preservation of Slovenian cultural heritage, the current state of cooperation, and certain problems that Slovenian musicologists still face when carrying out archival research, with special reference to the information recently added to the RISM online catalogue.

The Répertoire International des Sources musicales (The International Inventory of Musical Sources) is an international project for the global documentation of preserved musical sources (music manuscripts, printed music, writings on music and libretti) founded in 1952 by the International Musicological Society (IMS) and the International Association of Music Libraries, Archives and Documentation Centres (IAML). In 1967, Dragotin Cvetko was entrusted with the organisation of the quinquennial Congress of the International Musicological Society in Ljubljana. A series of lectures, round tables and meetings took place throughout the Slovenian capital from 3 to 8 September. The programme was accompanied by musical performances and four exhibitions, one of which was dedicated to preserved music manuscripts and prints dating from before 1800, which were exhibited at the National and University Library in Ljubljana (NUK). ${ }^{1}$ A bilingual catalogue of the exhibited manuscripts and prints was published together with other collections from 17 different archives and libraries. In the foreword to this catalogue Dragotin Cvetko commented that

the material for a musical history of Slovenia has suffered considerable damage during the centuries. For various reasons it has been in part destroyed or dispersed. Despite all this a considerable quantity has been preserved as is evidenced by researchers up to the present

1 Dragotin Cvetko, ed., Report of the Tenth Congress of the International Musicological Society, Ljubljana 1967 (Kassel: Bärenreiter, 1970), 495. 
day. Only in the last twenty years, however, have these been systematic and to achieve a complete picture much time and enthusiastic investigation will be needed. ${ }^{2}$

Although the study of primary music sources preserved on the Slovenian territory dates back at least to the second half of the nineteenth century, the cited paragraph from the aforementioned foreword to the 1967 catalogue confirms that archiving efforts in the field of Slovenian musicology were intensified in the 1950s. This was a direct result of collaboration between Ludvik Zepič, the first head of the Music Collection at NUK, and François Lesure, the director of the first Central Secretariat of RISM in Paris. ${ }^{3}$ Slovenia, then part of Yugoslavia, participated early on in this international, now global project and was included in its first two bibliographical publications in the series B/I-II or bibliographies of the printed collections from the sixteenth to the eighteenth century Recueils imprimés, with B/I published in 1960 and B/II in 1964. ${ }^{4}$ Zepič's collaboration with RISM was based primarily on the collection and cataloguing of printed music for the $\mathrm{B}$ series and from 1971 also individual prints before 1800 (A/I series), opera libretti and theoretical treatises up to 1800 Écrits imprimés concernant la musique of the series B/VI (Printed Writings about Music). ${ }^{5}$

The interest shifted partly to manuscripts of early music before 1850 after Ivan Klemenčič was appointed head of Music Collection at NUK in 1967. The same year, one of the exhibitions accompanying the Congress of the International Musicological Society showed some of the most important manuscripts and prints of early music from the Slovenian territory known at the time. The bilingual catalogue Music Manuscripts and Printed Music in Slovenia before 1800 by Janez Höfler and Ivan Klemenčič (containing objects from NUK, supplemented by several other collections of owning institutions from all over the country) was the first publication of its kind in Slovenia and remained the central reference literature for domestic and foreign researchers for a long time. ${ }^{6}$

2 Dragotin Cvetko, foreword to Glasbeni rokopisi in tiski na Slovenskem do leta 1800: katalog (Ljubljana: Narodna in univerzitetna knjižnica, 1967), 4.

3 Ivan Klemenčič, “RISM v Sloveniji," Muzikološki zbornik 38 (2002): 107, https://doi.org/10.4312/ mz.38.1.105-112.

4 RISM is divided into three main series - A, B and C - with further subdivisions. A/I indexes individually issued printed music before 1800 and A/II music manuscripts, mainly between 1600 and 1850. B indexes bibliographies organised by specific topics (for example printed anthologies, polyphonic music, music theory, etc.). C is the Directory of Music Research Libraries. The divisions between series have, however, been blurred by the RISM online catalogue, but some of the series have yet to be included in the online environment. See http://www.rism.info/publications.html.

5 François Lesure, Recueils imprimés: XVIe-XVIIe siècles (Munich; Duisburg: G. Henle, 1960); Recueils imprimés: XVIIIe siècle (Munich; Duisburg: G. Henle, 1964); Lesure, Écrits imprimés concernant la musique, 2 vols (Munich; Duisburg: G. Henle, 1971).

6 The catalogue includes music manuscripts from eight archives and libraries, all of which have music manuscript collections entered in the RISM online catalogue. Janez Höfler and Ivan Klemenčič, Glasbeni rokopisi in tiski na Slovenskem do leta 1800: katalog (Ljubljana: Narodna in univerzitetna knjižnica, 1967). 
In 1975, it was supplemented with additional information on manuscripts and printed items from seven Slovenian archives and libraries, including NUK. ${ }^{7}$

Almost a decade after the formal establishment of the Department of $\mathrm{Mu}-$ sicology at the Faculty of Arts of the University of Ljubljana in 1962, the idea of another musicological institution dedicated exclusively to research was born and officially realised in the autumn of 1980. Although the headquarters of RISM in Slovenia was located in the NUK Music Collection, the researchers of the newly founded Institute of Musicology, now part of the Research Centre of the Slovenian Academy of Sciences and Arts, made it one of their main goals to devote time and effort to collecting and preserving knowledge about early Slovenian musical heritage.

In 1987, Ivan Klemenčič emigrated from NUK to the Institute of Musicology ZRC SAZU. By the beginning of the 1990s, researchers at the institute had already collected information on about 1,300 units of music manuscripts and prints from seven different archives and libraries on the Slovenian territory, and compiled the General Register of Earlier Music Sources (1600-1850) Preserved in the Republic of Slovenia. ${ }^{8}$ The inventory was structured in the form of a traditional card catalogue, which, in addition to essential information on the material, contains at least one music incipit for music manuscripts (encoded main melodies of a certain representative voice or instrument of a work). ${ }^{9}$

In 1993, the RISM National Committee for Slovenia was established and Slovenia started to participate in the RISM A/II series (Music Manuscripts after 1600). ${ }^{10} \mathrm{~W}$ ith the introduction of the computer programme PIKaDo (Pflege und Informationsverarbeitung kategorisierter Dokumente) ${ }^{11}$ developed by RISM Germany, the cataloguing methodology for music manuscripts shifted from a traditional to a computer-based procedure. ${ }^{12}$ The decision to abandon the in-house development of a computer programme for the cataloguing of music manuscripts (and prints) at the institute was made due to

7 The typescript Music Manuscripts in Slovenia before 1800: Supplement for RISM (Ljubljana, 1975) is archived at the Institute of Musicology ZRC SAZU. Klemenčič, "RISM v Sloveniji," 108.

8 Darja Frelih, "Katalogiziranje glasbenih virov za RISM v Sloveniji," Muzikološki zbornik 38 (2002): 113, https://doi.org/10.4312/mz.38.1.113-118; Klemenčič, “RISM v Sloveniji," 109.

9 The size of a traditional catalogue slip, usually A5 format, dictates the amount of data it is possible to record. Since these slips were small in size, only essential, brief information could be included: siglum of the holding institution, the manuscript signature, name of the composer, diplomatic title (written exactly as it appears on the source), scoring summary (with number of parts and scores) and possible title page, information regarding the creation of the unit (manuscript or print), date of creation (or at least a wider defined period), copyist or former owner, size of material and one incipit. The card catalogue is still kept at the Institute of Musicology ZRC SAZU.

10 It is the most comprehensive guide available to music manuscripts created after 1600 , containing sources from collections from more than 35 countries around the world.

11 In English Maintenance and Information Processing of Categorised Documents. Frelih, "Katalogiziranje glasbenih virov," 114 .

12 See: http://www.rism.info/en/organisation/project-history.html. 
compatibility problems with the incipits, resulting from later attempts to convert the data and compare them with data from the collections of other countries contained in the RISM database. The installation of the RISM programme was more appropriate in this respect. ${ }^{13}$ The first results of participation in the computerised cataloguing of the A/II series were published in 1995 in the form of a CD-ROM (these were issued annually). ${ }^{14}$ The Slovenian cataloguers contributed 165 units from six archives. ${ }^{15}$

In 2002, Ivan Klemenčič and Darja Frelih participated in the international congress Scientific and Technological Challenges of Musicological Source Research at International Level, which was organised on the occasion of the $50^{\text {th }}$ anniversary of RISM. They presented the current status of the project in Slovenia. At that time, the Slovenian collection consisted of about 1,000 units or 1,400 works, 900 of which were included in the 2001 edition of the RISM CD-ROM. ${ }^{16}$

In June 2010, the RISM online catalogue was published for free for the first time, followed by a new cataloguing programme, Kallisto, for the holdings of music manuscripts in 2011, and by 2012 the RISM group at the Institute of Musicology had increased the number of entries in the RISM A/II database to about 2,900. New entries were added from the Ljubljana Cathedral, the Franciscan Monastery in Novo mesto and the Novo mesto chapter, and for the first time music collections, mainly from the Slovenian coastal area, were thoroughly arranged and catalogued: collections from the Episcopal Archives in Koper, the Koper Cathedral, the Provincial Archives in Koper, the Srečko Vilhar Central Library in Koper, the Parish Archives in Piran, the Minorite Monastery in Piran, and the Church of St Mauro in Izola. ${ }^{17}$ Among the most recent collections catalogued with Kallisto are the collections of the St John the Baptist Cathedral of Maribor, which was catalogued by Melanija Markovič in 2016. ${ }^{18}$

13 The development of a separate computer program for cataloguing manuscripts and prints was originally planned, and in 1991 cataloguing guidelines were even drawn up. Klemenčič, "RISM v Sloveniji," 109.

14 Before the CD-ROM, RISM data were published in the form of a microfiche, which could only contain a limited amount of data. See article "10 Years of the RISM Online Catalogue" for more information. Available at http://www.rism.info/en/home/newsdetails/select/rism_online_cata$\log /$ article/2/10-years-of-the-rism-online-catalog.html.

15 Klemenčič, "RISM v Sloveniji," 110.

16 Both Klemenčič and Frelih adapted their contributions into articles published in the first issue of volume 38 of the Muzikološki zbornik in 2002. See Klemenčič, "RISM v Sloveniji"; Frelih, "Katalogiziranje glasbenih virov".

17 Klemen Grabnar and Metoda Kokole, "RISM in Slovenia in the Past Decade: Newly Catalogued Music Collections, Especially Early $17^{\text {th }}$-Century Choirbooks" (paper presented at the RISM international conference Music Documentation in Libraries, Scholarship, and Practice, Mainz, Germany, June 2012,1-2).

18 Melanija Markovič, "Glasbeni arhiv starejših muzikalij v Stolni župniji sv. Janeza Krstnika v Mariboru” (Bachelor's thesis, University of Ljubljana, 2016). 
In 2016, Kallisto was replaced by a new cataloguing programme called Muscat, and the cataloguing process shifted to an online environment. Muscat is an open source, web-based, platform-independent programme developed by RISM UK, RISM Switzerland and the RISM Central Editorial Office. It is multilingual, with interfaces in English, German, French and Italian, and translations into Spanish and Portuguese are in preparation. ${ }^{19}$

My own collaboration with the Slovenian RISM group at the Institute of Musicology ZRC SAZU, which was part of the work on my master's thesis, was stimulated by the particularities of certain Slovenian repositories that house collections of early music manuscripts. Since many of them have neither their own financial means nor qualified staff to systematically arrange, inventory and properly store their material, the Institute of Musicology serves as a medium by providing them with the necessary tools and manpower to perform these tasks properly. RISM has been an extremely important part of this process in Slovenia since its foundation. Not only does it provide support in the form of technical and professional guidelines and a comprehensive platform for maintaining a freely accessible, comprehensive electronic register of all of the musical and non-musical elements of each composition, but the globally standardised cataloguing process also enables comparative analysis with the entire worldwide register. However, accelerated development and the ever-increasing number and complexity of the templates make cataloguing not only more accessible and user-friendly, but also increasingly costly and time consuming. The RISM working group for Slovenia is composed of the staff of the Institute of Musicology ZRC SAZU, who have their own individual projects and responsibilities. Very rarely is the work supported by state and municipal grants. Current funding does not allow for the employment of a person specifically designated for archive research and cataloguing. ${ }^{20}$ However, the work is sporadically carried out by young researchers, who use RISM as a tool in their master's and doctoral theses under the supervision of researchers at the institute. This not only relieves the burden of the researchers, but also gives the students an opportunity to gain experience in handling archive material and RISM.

My own contribution to the RISM online database is a collection of music manuscripts from the Abbey and Parish Church of St Daniel in Celje (SICo). ${ }^{21}$ The collection first received attention in 1981, when its first organiser, cataloguer and analyst became Danilo Pokorn. ${ }^{22}$ He prepared the catalogue in the traditional card form, which is still kept by the Institute of Musicology

19 See http://www.rism.info/community/muscat.html.

20 The only staff member of this kind was Darja Frelih between 1998 and 2010.

21 See Jana Erjavec, "Glasbeni arhiv starejših rokopisov v cerkvi Sv. Danijela v Celju," De musica disserenda 16, no. 2 (2020): 71-82.

22 Slovenska akademija znanosti in umetnosti, Letopis: 1981 (Ljubljana: SAZU, 1982), 227. 
ZRC SAZU, and in 1989 he presented his first results in the article "The Music Collection in the Abbot Church of St Daniel's, Celje". ${ }^{23}$ The repertoire of the collection, which otherwise includes both music manuscripts and prints from the eighteenth and nineteenth centuries, is quite a rich selection of works by various composers, from world-famous figures to rather unknown local representatives. It is mainly of a religious nature, but a considerable part is derived from contemporary theatrical musical genres. Many of these works are so-called contrafacta - they have been rededicated through textual adaptation for performance in a religious context. These phenomena are increasingly being discovered by certain European researchers as particularly common in all periods of the past, but have not yet aroused much interest in the contemporary Slovenian geographical area. ${ }^{24}$ The initial results of a statistical analysis of data extracted from the material (names of possible copyists, dedicatees and former owners, old shelf marks, stamps and other notes on bindings, covers, parts and scores, etc.) revealed some surprising facts about the origin and function of some of the compositions (such as the aforementioned contrafacta).$^{25}$ An uncomplicated, comprehensive and easily accessible catalogue of this collection will support future research efforts in the precise and thorough study of the material, thus enabling us to further develop our general understanding of eighteenth- and nineteenth-century music, both in the Slovenian and the wider European context.

The collection was first included in the RISM online catalogue in 2016. As the inventory compiled by Danilo Pokorn proved to be incomplete and contained a considerable number of errors due to certain limitations of the previous methodology, the Slovenian RISM group decided that it would be best to repeat both the quantitative and qualitative analysis of the collection under the new and improved research conditions.

The location and type of archives and libraries that house early music collections more or less determine the working conditions. Most of them are located outside the capital and are therefore accessible by car from the Institute of Musicology ZRC SAZU. Fieldwork and travel expenses are funded by the regular inventory programme or by a specific project, and in most cases

23 Danilo Pokorn, “Glasbena zbirka opatijske cerkve sv. Danijela v Celju," Muzikološki zbornik 25, no. 1 (1989): 107-120, https://doi.org/10.4312/mz.25.1.107-120.

24 For more information on existing research, see, e.g., Tomasz Jeż, "Contrafacta of Operatic Arias among the Dominicans of Baroque Silesia," De musica disserenda 11, nos. 1-2 (2015): 147-162; Milada Jonášová, "Kontrafakturen in der Böhmischen Kirchenmusik des 18. Jahrhunderts," Musicologica Brunensia 49, no. 2 (2014): 107-126; Marina Tofetti and Gabrielle Taschetti, eds., Contrafacta: Modes of Music Re-textualization in the Late Sixteenth and Seventeenth Century (Kraków: Musica Iagellonica, 2020); Undine Wagner, "Vom Dramma per Musica zur kirchenmusikalischen Praxis - Geistliche Kontrafakturen italienischer Opernarien in mährischen Klöstern und Kirchen," Musicologica Brunensia 49, no. 2 (2014): 139-167; etc.

Erjavec, "Glasbeni arhiv starejših rokopisov," 73-79. 
access to the collections depends on the curator's opening hours or availability. Whenever possible, the cataloguers borrow the materials and bring them to the Institute of Musicology, provided that an agreement is reached with the person responsible for the collection. Consideration should also be given to the limited space in the available vehicle, usually a passenger car that can only hold a certain amount of material.

The logistics of the work process must meet these conditions. The work must be divided into several phases of the visit to the host institutions. Although there is an increasing number of tools that can be used to carry out at least part of the work on site, such as so-called scanning tents, portable LED light tracing boards or pads and other special equipment that can be combined with laptops, tablets or smartphones, in many places there are other constraints that directly affect the use of such devices (old buildings with a limited number of power sockets, isolated locations with poor internet connections, etc.). Whenever possible, the best and most frequently chosen option is to borrow the materials and bring them to Ljubljana. This was our first step in working with the collection from Celje. The working conditions at the institute also allow for an unimpeded, uninterrupted, regular and continuous workflow.

Most of the material from SI-Co had already been organised by Danilo Pokorn and had been preserved in this state until our own examination. The second step was digitalisation. During this process, the materials were scanned and the scans were stored at the home institution and at the Institute of $\mathrm{Mu}-$ sicology ZRC SAZU. This not only allows the researchers to access the documents at any time, but also reduces the need for constant intervention in the physical material, which significantly reduces its decay. Ideally, these documents would be published online, especially since RISM offers the possibility to link digital resources with RISM records. This would allow other participants to contribute their knowledge and share their observations on the recorded metadata compared to the freely available digitised material.

The third step was to extract all possible information from the physical objects and enter it as metadata into the online RISM database. This was done using extensive guidelines from RISM and its latest cataloguing platform, Muscat, which has a wide range of available templates for different types of sources. This is one of the key features that sets Muscat apart from its predecessors. In addition to capturing music manuscripts, cataloguers can also capture printed music editions, handwritten or printed libretti, handwritten or printed treatises and even compound volumes (e.g., bound music manuscripts and prints). ${ }^{26}$

26 Muscat includes various RISM series (A/I, A/II, B/I), which are in one single database for the first time, having previously been managed in separate locations. See http://www.rism.info/community/muscat.html. 
The importance of a detailed and easily accessible register of all of the preserved musical sources of a certain time and space cannot be overestimated when it comes to correctly classifying unknown musical works, which is still one of the main problems of musicology today and was one of the main reasons for examining the collection from Celje more closely. ${ }^{27}$ The possibility of comparing the music incipits entered into the world census via RISM makes it possible to identify them in a previously unimaginable way. As Klaus Keil and Jennifer A. Ward noted:

\begin{abstract}
This is especially important for researchers working with manuscripts from time periods in which sources experienced broad geographical distribution and transmission and were frequently recorded anonymously. An incipit can identify a piece when its transmitted author or title cannot. ${ }^{28}$
\end{abstract}

This enabled me to identify even the least known authors, which would have been practically unimaginable in the days of Danilo Pokorn. The discussionlike feature in Muscat, which allows users to provide feedback and comments, is also very useful in this context.

Together with 275 entries from the Church of St Daniel, approximately 5,200 music manuscript entries have so far been included in the RISM online catalogue. These form the collections of music manuscripts from 14 of 36 locations in Slovenia, which have been included in the online directory of the RISM library sigla.

Despite the presence of RISM in Slovenia (and the Slovenian presence in RISM), which is approaching its $70^{\text {th }}$ anniversary, Slovenian musicology still faces many challenges in the field of archive research and preservation. There are still unstudied collections, and moreover, the results of "completed" research must be constantly reviewed, either due to the limited methods in the past or because of the constantly improving modern research conditions. In summary, to return to the words of Dragotin Cvetko, "to achieve a complete picture much time and enthusiastic investigation will be needed".

27 One of the greatest challenges faced when working with music manuscripts is to establish or verify the attribution of preserved works. This concerns not only the vast quantity of anonymous copies, but also sources that bear the alleged author's signature. Considerable caution is needed even in relation to the latter, since, as we know, instances where one and the same work is ascribed to different composers in different sources are rather more the rule than the exception. Some contemporary scholars have miscalculated in this respect, be it only in overinterpreting certain facts, such as mistaking the name of the scribe on the title page of a work for the name of the composer. As a consequence, their publications occasionally bring added confusion to the complex problem of attribution. Maciej Jochymczyk and Maksymilian Kapelański, “The Masses of Francesco Perneckher in the Collection of the Pauline Monastery at Jasna Góra (Częstochowa): Problems of Attribution and Source Studies,” Fontes Artis Musicae 66, no. 2 (2019): 164.

28 Klaus Keil and Jennifer A. Ward, "Applications of RISM data in digital libraries and digital musicology," International Journal on Digital Libraries 20, no. 1 (2019): 4. 


\section{Sources and bibliography}

"10 Years of the RISM Online Catalog." RISM. Accessed 12 September 2020. http://www. rism.info/en/home/newsdetails/select/rism_online_catalog/article/2/10-years-of-therism-online-catalog.html.

"History of the project." RISM. Accessed 12 September 2020. http://www.rism.info/en/ organisation/project-history.html.

"Muscat."RISM. Accessed 12 September 2020. http://www.rism.info/community/muscat.html.

"Publications." RISM. Accessed 12 September 2020. http://www.rism.info/publications.html.

Cvetko, Dragotin, ed. Report of the Tenth Congress of the International Musicological Society, Ljubljana 1967. Kassel: Bärenreiter, 1970.

Cvetko, Dragotin. Foreword to Glasbeni rokopisi in tiski na Slovenskem do leta 1800: katalog. [Music manuscripts and printed music in Slovenia before 1800: Catalogue] Ljubljana: Narodna in univerzitetna knjižnica, 1967.

Erjavec, Jana. "Glasbeni arhiv starejših rokopisov v cerkvi sv. Danijela v Celju." [The Collection of Early Music Manuscripts at the Church of St Daniel in Celje] De musica disserenda 16, no. 2 (2020): 71-82. https://doi.org/10.3986/dmd16.2.04.

Frelih, Darja. "Katalogiziranje glasbenih virov za RISM v Sloveniji." [Cataloguing for RISM in Slovenia] Muzikološki zbornik 38 (2002): 113-118. https://doi.org/10.4312/ mz.38.1.113-118.

Grabnar, Klemen, and Metoda Kokole. "RISM in Slovenia in the Past Decade: Newly Catalogued Music Collections, Especially Early 17th-Century Choirbooks." Paper presented at the RISM international conference Music Documentation in Libraries, Scholarship, and Practice, Mainz, Germany, June 2012. http:/www.rism.info/fileadmin/content/ community-content/events/RISM_Conference_2012/Grabnar.pdf.

Höfler,Janez, and Ivan Klemenčič. Glasbeni rokopisi in tiski na Slovenskem do leta 1800: kata$\log$ [Music manuscripts and printed music in Slovenia before 1800: Catalogue]. Ljubljana: Narodna in univerzitetna knjižnica, 1967.

Jeż, Tomasz. "Contrafacta of Operatic Arias among the Dominicans of Baroque Silesia." De musica disserenda 11, no. 1-2 (2015): 147-162. https://doi.org/10.3986/dmd11.1-2.09.

Jochymczyk, Maciej, and Maksymilian Kapelański. “The Masses Of Francesco Perneckher in the Collection of the Pauline Monastery at Jasna Góra (Częstochowa): Problems of Attribution and Source Studies." Fontes Artis Musicae 66, no. 2 (2019): 156-165. https:// www.muse.jhu.edu/article/729951.

Jonášová, Milada. "Kontrafakturen in der Böhmischen Kirchenmusik des 18. Jahrhunderts." Musicologica Brunensia 49, no. 2 (2014): 107-126. https://doi.org/10.5817/ MB2014-2-8.

Keil, Klaus, and Jennifer A. Ward. "Applications of RISM data in digital libraries and digital musicology." International Journal on Digital Libraries 20, no. 1 (2019): 3-12. https:// doi.org/10.1007/s00799-016-0205-3.

Klemenčič, Ivan. "RISM v Sloveniji." [RISM in Slovenia] Muzikološki zbornik 38 (2002): 105-112. https://doi.org/10.4312/mz.38.1.105-112.

Lesure, François. Écrits imprimés concernant la musique. 2 vols. Munich; Duisburg: G. Henle, 1971.

Lesure, François. Recueils imprimés: XVIe-XVIIe siècles; XVIIIe siècle. Munich; Duisburg: G. Henle, 1960-1964.

Markovič, Melanija. "Glasbeni arhiv starejših muzikalij v Stolni župniji sv. Janeza Krstnika v Mariboru." [The Repertoire of the Old Music Collection in the St John the Baptist Cathedral of Maribor] Bachelor's thesis, University of Ljubljana, 2016. https://repozitorij.uni-lj.si/IzpisGradiva.php?lang=slv\&id=98014. 
Pokorn, Danilo. “Glasbena zbirka opatijske cerkve sv. Danijela v Celju.” [The Music Collection in the Abbot Church of St Daniel's, Celje] Muzikološki zbornik 25, no. 1 (1989): 107-120. https://doi.org/10.4312/mz.25.1.107-120.

Schlager, Karlheinz, and Otto E. Albrecht. Einzeldrucke vor 1800. 9 vols. Kassel: Bärenreiter, 1971-1999.

Slovenska akademija znanosti in umetnosti. Letopis: 1981 [Yearbook]. Vol. 32. Ljubljana: SAZU, 1982. http://www.dlib.si/?URN=URN:NBN:SI:doc-UZDUK5A4.

Tofetti, Marina, and Gabrielle Taschetti, eds. Contrafacta: Modes of Music Re-textualization in the Late Sixteenth and Seventeenth Century. Kraków: Musica Iagellonica, 2020.

Wagner, Undine. "Vom Dramma per Musica zur kirchenmusikalischen Praxis - Geistliche Kontrafakturen italienischer Opernarien in mährischen Klöstern und Kirchen.” Musicologica Brunensia 49, no. 2 (2014): 139-167. https://doi.org/10.5817/MB2014-2-10.

\section{POVZETEK}

\section{RISM in popisovanje starejših glasbenih rokopisov v Sloveniji}

Slovenija sodeluje v projektu RISM (Répertoire International des Sources Musicales) že skoraj sedem desetletij. Med 50. in 60. leti prejšnjega stoletja, ko je bil sedež RISM-a v Sloveniji Narodna in univerzitetna knjižnica v Ljubljani, se je stroka osredotočala predvsem na starejše glasbene tiske, teoretična dela ter operne librete, nakar je pozornost preusmerila predvsem v popis glasbenih rokopisov. Muzikološki inštitut Znanstvenoraziskovalnega centra Slovenske akademije znanosti in umetnosti, ki je bil ustanovljen leta 1980, je vse od začetka sestavljal lasten listkovni katalog starejših glasbenih virov iz obdobja med 1600 in 1850, ki so se ohranili na tleh današnje Republike Slovenije. S selitvijo sedeža RISM-a v Sloveniji iz Narodne in univerzitetne knjižnice na Muzikološki inštitut leta 1987 se je Slovenija pridružila popisovanju glasbenih rokopisov v sklopu RISM-ove serije A/II. Leta 1993 bil ustanovljen področni odbor RISM za Republiko Slovenijo, ki je od centralne redakcije prevzel računalniški program za popisovanje glasbenih rokopisov, za kar se je odločil zaradi mednarodne kompatibilnosti podatkov.

$\mathrm{Na}$ arhivske raziskave starejše glasbene zapuščine v Sloveniji poleg RISM-a vpliva še mnogo drugih dejavnikov, s katerimi se slovenska muzikološka stroka spopada še danes: omejena finančna podpora, pomanjkanje časa ter kvalificirane delovne sile, ter oddaljenost večine hranišč. Kljub temu so člani RISM-ove skupine s pomočjo najnovejše tehnologije in smernic doslej uspeli popisati ok. 5200 glasbenih rokopisov iz približno polovice arhivov in knjižnic po Sloveniji.

Najnovejši prispevek slovenske delovne skupine v spletni katalog RISM je glasbeno-rokopisna zbirka cerkve sv. Danijela v Celju. Zbirko, odkrito leta 1980, je prvi uredil, popisal ter preučil Danilo Pokorn. Zavoljo napak, ki so se med katalogizacijo pripetile predvsem zaradi pomanjkljivosti metodologije $\mathrm{v}$ preteklosti, se je slovenska skupina za RISM odločila, da je potrebna ponovna obravnava v skladu s sodobnimi, izpopolnjenimi raziskovalnimi pogoji. Zbirka, ki sega v 18. in 19. stoletje, je bila prva, ki je bila popisana s pomočjo najnovejšega RISMovega programa za popisovanje, imenovanega Muscat. Gre za spletni program, neodvisen od operacijskega sistema, ki ponuja tudi izčrpna navodila za izpolnjevanje ter masko za vse vrste virov (predhodni programi so bili namenjeni le popisovanju glasbenih rokopisov). Ponuja vrsto novih možnosti, vključno s posebno možnostjo izmenjave mnenj med prijavljenimi uporabniki. Doslej so bili v spletni katalog RISM vključeni metapodatki o 275 bibliografskih enotah iz zbirke cerkve sv. Danijela v Celju. 


\section{ABOUT THE AUTHOR}

JANA ERJAVEC (jana.erjavec@zrc-sazu.si) received her BA and MA degrees in musicology from the University of Ljubljana, Faculty of Arts, in 2016 and 2019, respectively. She completed her master's thesis "The collection of early music manuscripts at the church of St. Daniel in Celje" in cooperation with the Institute of Musicology ZRC SAZU. She is currently a $\mathrm{PhD}$ candidate at the University of Ljubljana, Faculty of Arts, and a junior researcher at the Institute of Musicology ZRC SAZU.

\section{O AVTORICI}

JANA ERJAVEC (jana.erjavec@zrc-sazu.si) je leta 2016 diplomirala in leta 2019 magistrirala na Oddelku za muzikologijo Filozofske fakultete Univerze v Ljubljani. V sodelovanju z Muzikološkim inštitutom ZRC SAZU je pripravila zaključno nalogo z naslovom "Glasbeni arhiv starejših rokopisov v cerkvi sv. Danijela v Celju”, ki jo je uspešno zagovarjala septembra 2019. Oktobra istega leta se je na Filozofski fakulteti Univerze v Ljubljani vpisala v interdisciplinarni doktorski študijski program Humanistika in družboslovje ter obenem zaposlila kot mlada raziskovalka na Muzikološkem inštitutu ZRC SAZU. 